\title{
Spiroplasma monobiae sp. nov. from the Vespid Wasp Monobia quadridens (Hymenoptera: Vespidae)
}

\author{
R. F. WHITCOMB, ${ }^{1 *}$ J. G. TULLY, ${ }^{2}$ D. L. ROSE, ${ }^{2}$ P. CARLE, ${ }^{3}$ J. M. BOVÉ ${ }^{3}$ R. B. HENEGAR, ${ }^{1}$ \\ K. J. HACKETT, ${ }^{1}$ T. B. CLARK, ${ }^{1}$ M. KONAI, ${ }^{1}$ J. ADAMS, ${ }^{1}$ AND D. L. WILLIAMSON ${ }^{4}$ \\ Insect Biocontrol Laboratory, Beltsville Agricultural Research Center, Agricultural Research Service, U.S. \\ Department of Agriculture, Beltsville, Maryland 20705'1 Mycoplasma Section, Laboratory of Molecular \\ Microbiology, Frederick Cancer Research Facility, National Institute of Allergy and Infectious Diseases, \\ Frederick, Maryland 21702 $2^{2}$ Laboratoire de Biologie Cellulaire et Moléculaire, Institut Nationale de \\ Recherche Agronomique, 33883 Villenave d'Ornon Cedex, France ${ }^{3}$; and Department of Anatomical
} Sciences, State University of New York, Stony Brook, New York $11794^{4}$

\begin{abstract}
Spiroplasma strain MQ-1 ${ }^{\mathrm{T}}$ ( $\mathrm{T}=$ type strain) from the hemolymph of the vespid wasp Monobia quadridens differed serologically from other spiroplasma species, groups, and subgroups. Cells of strain $M Q-1^{T}$ were helical and motile and possessed a single cytoplasmic membrane, with no evidence of a cell wall. The organism grew in conventional mycoplasma medium, in serum fraction, SM-1, M1D, and SP-4 liquid media, and on SP-4 solid medium in either aerobic or anaerobic environments. The optimum temperature for growth was $32^{\circ} \mathrm{C}$, but multiplication occurred over a wide temperature range $\left(10\right.$ to $\left.37^{\circ} \mathrm{C}\right)$. The doubling time at $32^{\circ} \mathrm{C}$ in M1D medium was $1.9 \mathrm{~h}$. Strain MQ-1 ${ }^{\mathrm{T}}$ catabolized glucose but hydrolyzed neither arginine nor urea. Previous work showed that strain MQ-1 ${ }^{\mathrm{T}}$ has a unique methylase, previously known only in eucaryotes. Also, strain MQ-1 ${ }^{\mathrm{T}}$ induces production of tumor necrosis factor in bone marrow macrophages. The guanine-plus-cytosine content of the DNA was $28 \pm 1$ mol\%. The genome size of strain MQ-1T was $940 \mathrm{~kb}(627 \mathrm{MDa})$; a similar strain, MQ-8, had a genome size of $985 \mathrm{~kb}(657 \mathrm{MDa})$. Strain MQ-1 ${ }^{\mathrm{T}}$ and its allies have the smallest genomes known in the genus Spiroplasma. Strain MQ-1 (= ATCC 33825) is designated the type strain of a new species, Spiroplasma monobiae.
\end{abstract}

The genus Spiroplasma (36), originally thought to consist of plant pathogens (22), was later shown, largely through the efforts of T. B. Clark and his associates $(7,15)$, to be associated with arthropods. As the immense diversity of this genus unfolded, numerous interesting properties emerged. For example, group I organisms (2) were the only spiroplasmas found to be associated with plant disease or with plant-sucking bugs. Yet, the subgroup I-2 spiroplasma, Spiroplasma melliferum (8), which was closely related to the plant spiroplasmas, was primarily associated with bees. One subgroup of this cluster (subgroup I-6), which appears to occur in the insect-plant surface habitat (15), had a guanineplus-cytosine $(\mathrm{G}+\mathrm{C})$ content that was higher than the $\mathrm{G}+\mathrm{C}$ contents of its cohort subgroups (5). Another spiroplasma (subgroup I-4), isolated only once, appeared to be associated with ticks. Group II spiroplasmas (34) produced sex ratio abnormalities in Drosophila flies. Group III spiroplasmas (9) (Spiroplasma floricola) proved to be associated with magnoliaceous flowers and their beetle and fly visitors and to have idiosyncratic metabolic pathways (6) that were readily studied because of the rapid growth of the species. Group IV appeared to be a widely distributed cluster of spiroplasmas, some of whose members, including type strain B31 (Spiroplasma apis), were pathogenic $(19,20)$ for honeybees (Apis mellifera). Groups V (Spiroplasma mirum [30]) and VI (29) were associated with ticks. Thus, each of the first six established spiroplasma groups appeared to possess unusual biological and/or ecological properties.

For some time, the group VII spiroplasmas, strain MQ-1 ${ }^{\mathrm{T}}$ ( $\mathrm{T}=$ type strain) and its allies, appeared to be exceptions to the emerging uniqueness of newly discovered strains. However, in 1985 Nur et al. (21) discovered that strain MQ-1 ${ }^{\mathrm{T}}$ had

\footnotetext{
${ }^{*}$ Corresponding author.
}

a unique methylase, previously recognized only in eucaryotes. In addition, the membranes of strain $\mathrm{MQ}-1^{\mathrm{T}}$ were shown to stimulate production of tumor necrosis factor by bone marrow macrophages (23). Furthermore, the genome sizes reported here for two group VII strains are the smallest genome sizes known for spiroplasmas. Thus, group VII spiroplasmas have joined predecessor groups in possession of unique features.

In this communication, we present the results of a taxonomic study of strain MQ- $1^{\mathrm{T}}$, organized by the proposed (16) minimal requirements for assignment of binomial names to mollicutes. As a result of this study, we designate strain MQ-1 (= ATCC 33825) the type strain of a new species, Spiroplasma monobiae.

\section{MATERIALS AND METHODS}

Spiroplasma strains. The techniques used for the isolation of spiroplasmas from insects have been described previously (18). Strain MQ-1 ${ }^{\mathrm{T}}$ was isolated and cultivated by T. B. Clark from the hemolymph of an adult Monobia quadridens wasp collected in Maryland. Some genomic and serologic features of the organism were reported earlier $(5,28)$. Strain MQ-1 ${ }^{\mathrm{T}}$ was purified by conventional filtration-cloning techniques (26).

Culture media and cultivation techniques. Strain MQ- ${ }^{\mathrm{T}}$ was grown in a primary culture in SM-1 liquid medium (32) at $30^{\circ} \mathrm{C}$. After three to five early broth passages, the isolate was lyophilized. For characterization, the dried culture was revived and passaged twice at $30^{\circ} \mathrm{C}$ before cloning in SM-1 broth. Following filtration-cloning (26), a triply cloned strain was designated MQ-1 ${ }^{\mathrm{T}}$ and was used in characterization studies. Other culture media used included (32) M1D and SP-4 media, conventional mycoplasma medium (10), and serum fraction broth supplemented with $1 \%$ bovine serum 
fraction (27). A solid formulation of each of these media was prepared by adding Noble agar (Difco Laboratories, Detroit, Mich.) to final concentrations of 0.8 to $2.25 \%$. Agar cultures were incubated at $30^{\circ} \mathrm{C}$, either aerobically with or without 5\% carbon dioxide (GasPak System [BBL Microbiology Systems, Cockeysville, Md.]) or anaerobically (hydrogen GasPak system [BBL]).

Temperature requirements for growth were assessed by preparing 10-fold dilutions of strain MQ- ${ }^{T}$ in M1D broth. One series of dilutions was incubated at each of nine temperatures $\left(5,10,15,20,25,30,32,37\right.$, and $\left.41^{\circ} \mathrm{C}\right)$. Spiroplasma growth was assessed by recording medium indicator change and/or by microscopic enumeration of helical filaments in the cultures. Each series was incubated for 40 days. The doubling times at each temperature were computed by fitting the temperature-time curves to a logistic growth equation (17).

Morphological studies. Cells of strain $\mathrm{MQ}-1^{\mathrm{T}}$ in broth cultures in logarithmic phase were examined by dark-field microscopy (magnification, $\times 1,250$ ). For electron microscopic examination, the strain was grown in $20 \mathrm{ml}$ of broth and pelleted by centrifugation. The pelleted cells were fixed for $2 \mathrm{~h}$ in $3 \%$ glutaraldehyde, postfixed in $1 \%$ osmium tetroxide for $1 \mathrm{~h}$, dehydrated in acetone, embedded in Epon, sectioned, and stained with $1 \%$ aqueous uranyl acetate and Reynold's lead citrate.

Sterol requirements. Sterol requirements for growth were assayed by a standard broth culture method (25).

Tests for biological and biochemical properties. The procedures used for demonstration of carbohydrate fermentation (1) and arginine and urea hydrolysis (1), the hemadsorption assay (12), and the film and spot reaction (11) have been described earlier. Filtration characteristics were measured in M1D broth by techniques reported previously (26).

Serological tests. Antiserum to strain MQ- $1^{\mathrm{T}}$ was raised in rabbits as previously described (37). Hyperimmune antisera to all established Spiroplasma species and groups were obtained from the reference collections at the Agricultural Research Center in Beltsville, Md., and the National Institute of Allergy and Infectious Diseases in Frederick, Md. These antisera and strain MQ- $1^{\mathrm{T}}$ were tested in a standard disc growth inhibition test (33). Metabolism inhibition and deformation tests were employed as previously described $(35,37)$.

Genomic analysis. Techniques for extraction and purification of chromosomal DNA from mollicutes have been described previously (3). The $\mathrm{G}+\mathrm{C}$ content of purified strain MQ-1 ${ }^{\mathrm{T}}$ DNA was determined by buoyant density, melting temperature, and high-performance liquid chromatography methods (4). Purified DNA from Spiroplasma citri (genome size, approximately $1,186 \mathrm{MDa} ; \mathrm{G}+\mathrm{C}$ content, $26 \pm 1 \mathrm{~mol} \%$ ) was used as a reference. The genome size was determined by pulsed-field gel electrophoresis as described by Grau et al. (13).

\section{RESULTS AND DISCUSSION}

Cultural and morphological properties. Strain $\mathrm{MQ}-1^{\mathrm{T}}$ grew well in liquid SM-1, M1D, and SP-4 media and on SP-4 solid medium. The strain also grew in conventional mycoplasma medium or bovine serum fraction. Growth occurred over a temperature range of 10 to $37^{\circ} \mathrm{C}$; optimum growth was observed at $32^{\circ} \mathrm{C}$, with a doubling time of $1.9 \mathrm{~h}$. Doubling times at $10,15,20,25,30$, and $37^{\circ} \mathrm{C}$ were $80.2,15.6,6.3,3.4$,

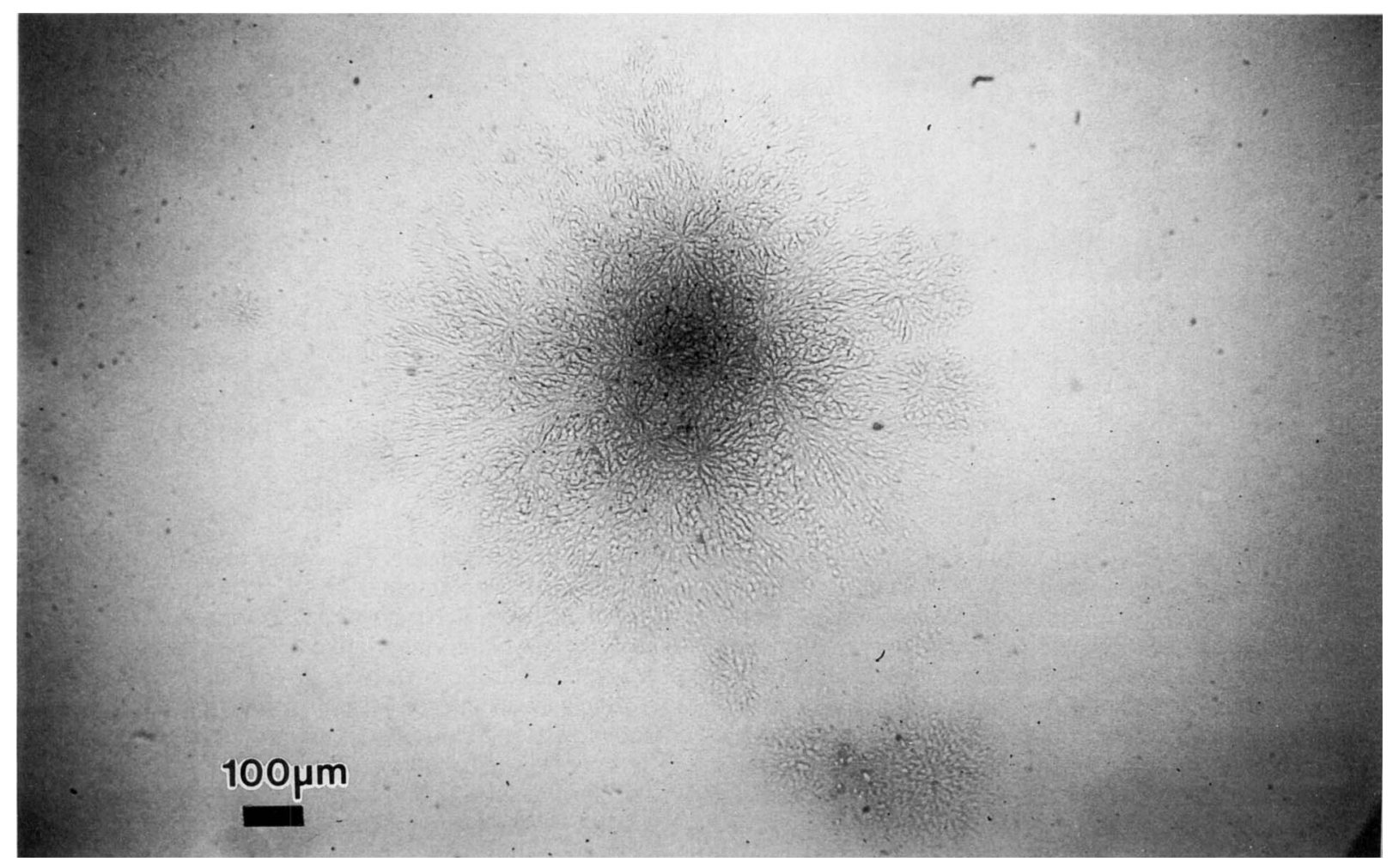

FIG. 1. Colonies of strain MQ-1 ${ }^{\mathrm{T}}$ on SP-4 agar medium containing $2.25 \%$ agar after 3 days of incubation at $30^{\circ} \mathrm{C}$ under aerobic conditions. 


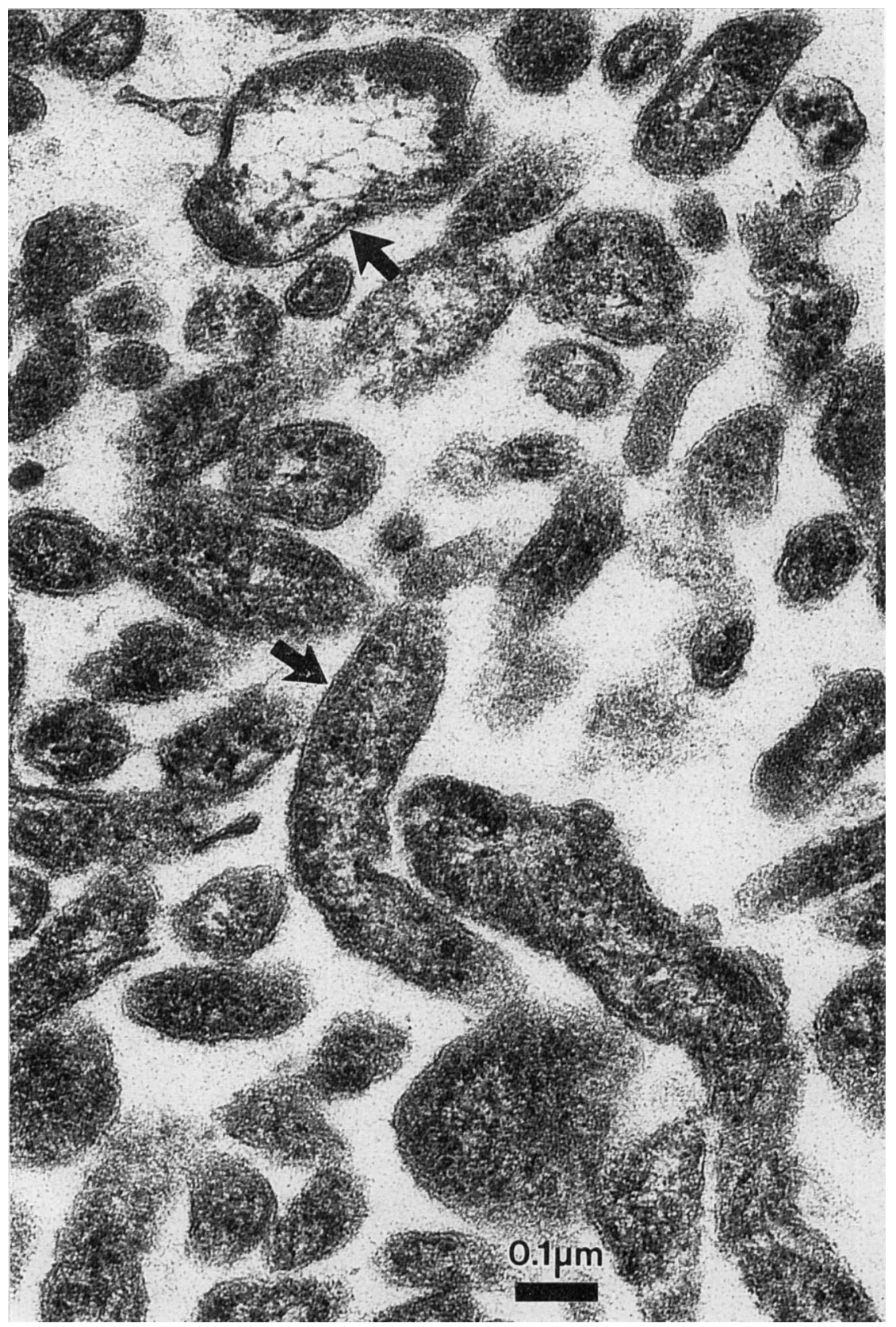

FIG. 2. Electron micrograph of a sectioned and stained cell pellet of strain MQ- ${ }^{\mathrm{T}}$. Sections were stained with $2 \%$ aqueous uranyl acetate and Reynold's lead citrate. The arrows indicate the unit membrane.

2.4 , and $20.2 \mathrm{~h}$, respectively. Colonies of strain $\mathrm{MQ}-1^{\mathrm{T}}$ on SP-4 agar medium containing $2.25 \%$ agar (Fig. 1) were diffuse; colonies having fried-egg morphology were never observed. Growth of strain $\mathrm{MQ}-1^{\mathrm{T}}$ on solid medium was observed on agar plates incubated aerobically at $30^{\circ} \mathrm{C}$ or when the plates were placed in GasPak systems with enhanced carbon dioxide atmospheres.

Logarithmic-phase cultures of strain $\mathrm{MQ}-1^{\mathrm{T}}$ examined by dark-field microscopy contained numerous long, helical, motile filaments. The cells of the organism examined by electron microscopy were filamentous and were surrounded by a single cytoplasmic membrane (Fig. 2), with no evidence of a cell wall.
Sterol requirement. The response of strain $\mathrm{MQ}-1^{\mathrm{T}}$ to cholesterol supplementation of serum-free SP-4 medium is shown in Table 1. No growth was apparent in base broth, but growth was observed when 5 to $20 \mu \mathrm{g}$ of cholesterol per ml was included.

Biochemical and biological properties. Strain MQ-1 ${ }^{\mathrm{T}}$ produced acid from glucose, but no evidence of arginine or urea hydrolysis was observed. Strain MQ-1 ${ }^{\mathrm{T}}$ produced the film and spot reaction, but colonies of the organism on an agar medium did not hemadsorb guinea pig erythrocytes. Passage of broth cultures of strain MQ- ${ }^{\mathrm{T}}$ through 450 -nm-pore-size membrane filters reduced the viable-cell titer 10 -fold to $10^{9}$ color-changing units per $\mathrm{ml}$. The titer of the broth culture 
TABLE 1. Growth response of strain MQ-1 ${ }^{\mathrm{T}}$ to cholesterol

\begin{tabular}{lcc}
\hline $\begin{array}{c}\text { Supplement(s) added to serum-free } \\
\text { base medium }\end{array}$ & $\begin{array}{c}\text { Cholesterol } \\
\text { concn }(\mu \mathrm{g} / \mathrm{ml})\end{array}$ & $\begin{array}{c}\text { Amt of protein } \\
(\mathrm{mg} / 100 \mathrm{ml})\end{array}$ \\
\hline $17 \%$ fetal bovine serum (control) & 0 & 2.80 \\
None & 0 & IG $^{a}$ \\
$1 \%$ albumin, 0.01\% Tween 80, and & 0 & IG \\
$10 \mu \mathrm{g}$ of palmitic acid per ml & 1 & IG \\
& 5 & 0.23 \\
& 10 & 0.90 \\
& 20 & 1.98 \\
\hline
\end{tabular}

${ }^{a}$ IG, insufficient growth for detection.

filtrates obtained after passage through $300-$ and $220-\mathrm{nm}$ pore-size membrane filters was reduced to $10^{6}$ color-changing units per $\mathrm{ml}$; the $100-\mathrm{nm}$-pore-size membrane filtrate was free of viable cells.

Serological tests. Metabolism inhibition and spiroplasma deformation tests (28) indicated that strain MQ-1 ${ }^{\mathrm{T}}$ was not related serologically to representatives of established groups $(14,28)$ or species of the genus Spiroplasma.

Genome size and DNA base composition. The genome size of strain MQ- ${ }^{\mathrm{T}}$, as determined by pulsed-field gel electrophoresis, was $940 \mathrm{~kb}(627 \mathrm{MDa})$, and the genome size of strain MQ-8 was $985 \mathrm{~kb}$ (657 MDa). Thus, strain MQ-1 ${ }^{\mathrm{T}}$ has the smallest genome of all of the spiroplasmas examined so far. The $\mathrm{G}+\mathrm{C}$ base composition of the DNA of strain MQ-1 ${ }^{\mathrm{T}}$ was $28 \pm 1 \mathrm{~mol} \%$.

Habitat. Strain MQ-1 ${ }^{\mathrm{T}}$ and isolate MQ-7 were isolated from hemolymph samples from male vespid wasps $(M$. quadridens). Two isolates (MQ-8 and MQ-9) serologically identical to strain $\mathrm{MQ}-1^{\mathrm{T}}$ were isolated from the guts of wasps; most mollicutes cultivated from insects are isolated from guts $(7,8,15,36)$. Some mollicutes that reside in insect hemolymph, such as $S$. melliferum (8) and $S$. apis (19), reduce the longevity of the host. Whereas $S$. melliferum titers in bee hemolymph reach $10^{10}$ organisms per ml, strain MQ $-1^{\mathrm{T}}$ had a titer of $7 \times 10^{7}$ organisms per $\mathrm{ml}$ in the wasps (15). Because the wasp host of strain $\mathrm{MQ}-1^{\mathrm{T}}$ is a predator, it is possible that the natural maintenance of this spiroplasma involves prey insects. The pathogenicity of strain MQ- $1^{\mathrm{T}}$ for $M$. quadridens or other insects has not been determined.

The properties described here for strain MQ- ${ }^{\mathrm{T}}$ fulfill the proposed criteria (16) for species of the class Mollicutes, including the absence of a cell wall, filterability, lack of reversion to walled bacteria when the organism is grown in antibiotic-free media, and penicillin resistance. The growth requirement for sterol or serum, the inability to utilize urea, helicity, and motility place this organism in the family Spiroplasmataceae (24). Molecular phylogenetic studies have shown that strain $\mathrm{MQ}-1^{\mathrm{T}}$ belongs to a cluster of insect-associated spiroplasma species (31). Finally, serologic comparison of strain MQ-1 ${ }^{\mathrm{T}}$ with other Spiroplasma species and with other unclassified spiroplasma strains that probably represent putative species demonstrated the uniqueness of this new insect strain. On the basis of the relationship of the spiroplasma to its host, we propose the name Spiroplasma monobiae for this organism. The taxonomic description below summarizes the properties of the organism.

Spiroplasma monobiae sp. nov. Spiroplasma monobiae (mon. o' bi. ae. M.L. n. Monobia, a genus of vespid wasps; M.L. gen. n. monobiae, of the genus Monobia, from which the organism was isolated). Cells are helical, motile filaments. Cells lack true cell walls. Colonies on solid medium containing $2.25 \%$ Noble agar are diffuse, never with a fried-egg appearance.

Chemoorganotroph. Acid produced from glucose. Does not hydrolyze arginine or urea.

Film and spot reaction negative. Does not hemadsorb guinea pig erythrocytes.

Cholesterol or serum required for growth.

Temperature range for growth, 10 to $37^{\circ} \mathrm{C}$; optimum growth occurs at $32^{\circ} \mathrm{C}$ with a doubling time of $1.9 \mathrm{~h}$.

Serologically distinct from other established Spiroplasma species. Isolated from the hemolymph of an adult vespid wasp (M. quadridens). Pathogenicity for insects not determined.

The $\mathrm{G}+\mathrm{C}$ content of the DNA is $28 \pm 1 \mathrm{~mol} \%$. The genome size is $940 \mathrm{~kb}(627 \mathrm{MDa})$.

The type strain is MQ-1 (= ATCC 33825).

\section{ACKNOWLEDGMENTS}

This work was supported in part by Binational Agricultural Research and Development grant US-1902-90R and by U.S. Department of Agriculture Potato Research grants.

\section{REFERENCES}

1. Aluotto, B. B., R. G. Wittler, C. O. Williams, and J. E. Faber. 1970. Standardized bacteriologic techniques for characterization of Mycoplasma species. Int. J. Syst. Bacteriol. 20:35-58.

2. Bové, J. M., C. Mouches, P. Carle-Junca, J. R. Degorce-Dumas, J. G. Tully, and R. F. Whitcomb. 1983. Spiroplasmas of group I. The Spiroplasma citri cluster. Yale J. Biol. Med. 56:573-582.

3. Carle, P., C. Saillard, and J. M. Bové. 1983. DNA extraction and purification. Methods Mycoplasmol. 1:295-299.

4. Carle, P., C. Saillard, and J. M. Bové. 1983. Determination of guanine plus cytosine content of DNA. Methods Mycoplasmol. 1:301-308.

5. Carle, P., J. G. Tully, R. F. Whitcomb, and J. M. Bové. 1989. Size of the spiroplasmal genome and guanine plus cytosine content of spiroplasmal DNA. Zentralbl. Bakteriol. Suppl. 20:889-892.

6. Charbonneau, D. 1984. Ph.D. thesis. Cornell University, Ithaca, N.Y.

7. Clark, T. B. 1982. Spiroplasmas: diversity of arthropod reservoirs and host-parasite relationships. Science 217:57-59.

8. Clark, T. B., R. F. Whitcomb, J. G. Tully, C. Mouches, C. Saillard, J. M. Bové, H. Wróblewski, P. Carle, D. L. Rose, and D. L. Williamson. 1985. Spiroplasma melliferum sp. nov., a new species from the honeybee (Apis mellifera). Int. J. Syst. Bacteriol. 35:296-308.

9. Davis, R. E., I.-M. Lee, and J. F. Worley. 1981. Spiroplasma floricola, a new species isolated from surfaces of flowers of the tulip tree, Liriodendron tulipifera L. Int. J. Syst. Bacteriol. 31:456-464.

10. Edward, D. G. ff. 1947. A selective medium for pleuropneumonia-like organisms. J. Gen. Microbiol. 1:238-243.

11. Freundt, E. A. 1983. Film and spot production. Methods Mycoplasmol. 1:373-374.

12. Gardella, R. S., and R. A. Del Giudice. 1983. Hemagglutination, hemadsorption, and hemolysis. Methods Mycoplasmol. 1:379384.

13. Grau, O., F. Laigret, P. Carle, J. G. Tully, D. L. Rose, and J. M. Bové. 1991. Identification of a plant-derived mollicute as a strain of an avian pathogen, Mycoplasma iowae, and its implications for mollicute taxonomy. Int. J. Syst. Bacteriol. 41:473-478.

14. Guo, Y. H., T. A. Chen, R. F. Whitcomb, D. L. Rose, J. G. Tully, D. L. Williamson, X. D. Ye, and Y. X. Chen. 1990. Spiroplasma chinensis sp. nov. from flowers of Calystegia hederacea in China. Int. J. Syst. Bacteriol. 40:421-425.

15. Hackett, K. J., and T. B. Clark. 1989. The ecology of spiroplasmas, p. 113-200. In R. F. Whitcomb and J. G. Tully (ed.), The mycoplasmas, vol. 5. Academic Press, Inc., New York.

16. International Committee on Systematic Bacteriology Subcommit- 
tee on the Taxonomy of Mollicutes. 1979. Proposal of minimal standards for descriptions of new species of the class Mollicutes. Int. J. Syst. Bacteriol. 29:172-180.

17. Konai, M., E. A. Clark, and R. F. Whitcomb. 1992. Temperature ranges and optima of spiroplasmas. IOM Letters 2:137.

18. Markham, P. G., T. B. Clark, and R. F. Whitcomb. 1983. Culture techniques for spiroplasmas from arthropods. Methods Mycoplasmol. 1:217-223.

19. Mouches, C., J. M. Bové, J. Albisetti, T. B. Clark, and J. G. Tully. 1982. A spiroplasma of serogroup IV causes a May disease-like disorder of honeybees in southwestern France. Microb. Ecol. 8:387-399.

20. Mouches, C., J. M. Bové, J. G. Tully, D. L. Rose, R. E. McCoy, P. Carle-Junca, M. Garnier, and C. Saillard. 1983. Spiroplasma apis, a new species from the honey bee (Apis mellifera). Ann. Microbiol. (Paris) 134A:383-397.

21. Nur, I., M. Szyf, A. Razin, G. Glaser, S. Rottem, and S. Razin. 1985. Procaryotic and eucaryotic traits of DNA methylation in spiroplasmas (mycoplasmas). J. Bacteriol. 164:19-24.

22. Saglio, P., M. L'Hospital, D. Lafièche, G. Dupont, J. M. Bové, J. G. Tully, and E. A. Freundt. 1973. Spiroplasma citri gen. and sp. n.: a mycoplasma-like organism associated with "stubborn" disease of citrus. Int. J. Syst. Bacteriol. 23:191-204.

23. Sher, T., A. Yamin, M., S. Rottem, and R. Gallily. 1990. In vitro induction of tumor necrosis factor $\alpha$, tumor cytolysis, and blast transformation by Spiroplasma membranes. J. Natl. Cancer Inst. 82:1142-1145.

24. Skripal, I. G. 1983. Revival of the name Spiroplasmataceae fam. nov., nom. rev., omitted from the 1980 Approved Lists of Bacterial Names. Int. J. Syst. Bacteriol. 33:408.

25. Tully, J. G. 1983. Tests for digitonin sensitivity and sterol requirements. Methods Mycoplasmol. 1:355-362.

26. Tully, J. G. 1983. Cloning and filtration techniques for mycoplasmas. Methods Mycoplasmol. 1:173-177.

27. Tully, J. G. 1984. Family II. Acholeplasmataceae Edward and Freundt 1979, p. 775-781. In N. R. Krieg and J. G. Holt (ed.), Bergey's manual of systematic bacteriology, vol. 1. Williams and Wilkins, Baltimore.
28. Tully, J. G., D. L. Rose, E. Clark, P. Carle, J. M. Bové, R. B. Henegar, R. F. Whitcomb, D. E. Colflesh, and D. L. Williamson. 1987. Revised group classification of the genus Spiroplasma (class Mollicutes), with proposed new groups XII to XXIII. Int. J. Syst. Bacteriol. 37:357-364.

29. Tully, J. G., D. L. Rose, C. E. Yunker, J. Cory, R. F. Whitcomb, and D. L. Williamson. 1981. Helical mycoplasmas (spiroplasmas) from Lxodes ticks. Science 212:1043-1045.

30. Tully, J. G., R. F. Whitcomb, D. L. Rose, and J. M. Bové. 1982. Spiroplasma mirum, a new species from the rabbit tick (Haemaphysalis leporispalustris). Int. J. Syst. Bacteriol. 32:92100.

31. Weisburg, W. G., J. G. Tully, D. L. Rose, J. P. Petzel, H. Oyaizu, D. Yang, L. Mandelco, J. Sechrest, T. G. Lawrence, J. V. Etten, J. Maniloff, and C. R. Woese. 1989. A phylogenetic analysis of the mycoplasmas: basis for their classification. J. Bacteriol. 171:6455-6467.

32. Whitcomb, R. F. 1983. Culture media for spiroplasmas. Methods Mycoplasmol. 1:147-158.

33. Whitcomb, R. F., J. G. Tully, P. McCawley, and D. L. Rose. 1982. Application of the growth inhibition test to Spiroplasma taxonomy. Int. J. Syst. Bacteriol. 32:387-394.

34. Williamson, D. L., and D. F. Poulson. 1979. Sex ratio organisms (spiroplasmas) of Drosophila, p. 175-208. In R. F. Whitcomb and J. G. Tully (ed.), The mycoplasmas, vol. 3. Academic Press, Inc., New York.

35. Williamson, D. L., J. G. Tully, and R. F. Whitcomb. 1979. Serological relationships of spiroplasmas as shown by combined deformation and metabolism inhibition tests. Int. J. Syst. Bacteriol. 29:345-351.

36. Williamson, D. L., J. G. Tully, and R. F. Whitcomb. 1989. The genus Spiroplasma, p. 71-111. In R. F. Whitcomb and J. G. Tully (ed.), The mycoplasmas, vol. 5. Academic Press, Inc., New York.

37. Williamson, D. L., R. F. Whitcomb, and J. G. Tully. 1978. The spiroplasma deformation test. Int. J. Syst. Bacteriol. Curr. Microbiol. 1:203-207. 